\title{
THE EFFECTIVENESS OF VIRTUAL CLASSROOM IN TOEFL PREPARATION FOR STUDENTS OF NURSING
}

\author{
Nyayu Yayu Suryani \\ STIK Siti Khadijah \\ Email: nyayu.ys@stikes-sitikhadijah.ac.id
}

\begin{abstract}
Communication technology has grown dramatically in Indonesia. Virtual classroom is an integration of information technology through the use of the internet to connect teachers and students. The aim of this research is to find out the effectiveness the using virtual classroom in TOEFL preparation and to improve students' score in TOEFL preparation. The population in this research was all of students Nursing Science Study Program Institute of Health Science and Technology of Muhammadiyah Palembang. In order to select the sample, the purposive sampling technique will be implemented, the sample of this research was the seventh semester students of Institute of Health Science and Technology Muhammadiyah Palembang. Nursing science Study program in Academic Year 2020/2021. The instrument of this research was the practice test TOEFL (Phillips, 2004). The data collection of this research is carried out online through Zoom meeting. To verify the hypotheses, the data used paired sample t-test and independent sample t-test was 0.008 which was lower than 0.05.The findings show the positive effects using virtual classroom in TOEFL preparation.
\end{abstract}

\section{Keywords: TOEFL preparation; technology; virtual classroom}

\section{INTRODUCTION}

The TOEFL (Test of English as a Foreign Language) is a test that assesses a person's ability to comprehend English. This is one of Indonesia's most popular tests, particularly for meeting university requirements and obtaining scholarships. Teaching TOEFL, like teaching English in general, has been a difficult task. Teaching TOEFL to Indonesian adult learners, on the other hand, is extremely problematic. They often insist on a high grade, but as time passes or the materials become more complex, they lose motivation (Wulandari, 2016). For a variety of purposes, the Test of English as a Foreign Language or TOEFL has become the most difficult requirement for scholarship and work applications in Indonesia(Munadia, 2016).

The TOEFL test or Test of English as a Foreign Language is the most commonly accepted English language test in the world, with over 10,000 schools, universities, and agencies in over 130 countries accepting it. The TOEFL test will help you get to wherever you 
want to learn. The TOEFL is a test that assesses English language proficiency in people who do not speak English as their first language. More than 7,500 colleges, universities, and licensing agencies in over 130 countries recognize TOEFL ratings (ETS, 2009).

For some students, the TOEFL exam has become a challenge. TOEFL scores have long been used as a metric for assessing university graduates' English proficiency. In order to complete their studies, students in the English and Literature Department must take not only a comprehension exam but also a TOEFL test. The fact that some English students struggled with the TOEFL test can be seen on the announcement board in the English and Literature Laboratory, where only four or five students were able to obtain a score of 500. The TOEFL was chosen because it was the most widely used criterion reference test for foreign language learners, especially in Indonesia(Rezkiani, 2019).

Meanwhile, the TOEFL is the only application matric that is universal to foreign applications from a wide range of academic backgrounds, and the test results are often used for purposes other than those intended, such as predicting student academic performance (Isaac and Justin,2009). In contrast, the TOEFL is a test that assesses a person's ability to use and understand English. It is one of the most significant factors in international students' academic success or failure (Kurasi,2012). As a result, the researcher may conclude that TOEFL is a test for students studying English as a foreign language who use it as a method to achieve their objectives. Students believe that the online community discussion feature will enable them to promote and support their language learning (Kabilan et al., 2010).

There is now an online TOEFL preparation course available in Indonesia. More than 119.000 students from almost all over Indonesia, as well as Indonesian students living abroad, have enrolled in this online course (Sudrajat \& Astuti,2018). A large number of students apply to enter this TOEFL training online course for each class enrollment. It shows that Indonesian students still have a strong desire to learn English, and that this online course has a positive effect on them. To help its learning curriculum, this online course combines social media such as Facebook, a blog, and YouTube. The Test of English as a Foreign Language (TOEFL) has become extremely common for both academic and non-academic purposes. TOEFL is used as one of the criteria of educational institutions' admission exams and school-leaving assessments for academic purposes (Papageorgiou \& Cho, 2014). TOEFL is used for non-academic purposes to assess passive English skills, such as listening and reading, among eligible workers in various companies. As a result, those who pass the TOEFL with such scores are supposed to pass the standard test or be recruited as expected.

According to (Nimasari et al., 2019) For a variety of reasons, the Test of English as a Foreign Language or TOEFL has been the most difficult prerequisite for scholarship and work 
applications in Indonesia. For instance, it is difficult for those whose academic field of study is not English. It is normal to need to take several tests in order to obtain the desired result. Second, the TOEFL test in Indonesia costs about \$40. Although it does not seem to be very expensive, retaking the exam would be costly. These reasons undoubtedly necessitate a significant amount of effort on the part of the test takers. Finally, organizations in major cities are the only ones that administer the ETS-mandated TOEFL exam.

The TOEFL is a structured test used to evaluate a person's English proficiency as a foreign language speaker. This test was created by the Educational Testing Service, or ETS as it is more commonly known. According to other sources, Brown believes the TOEFL is one of the commercially produced English proficiency tests (Brown, 2004). Sharpe, like Brown, stressed that the TOEFL is a measure of English as a second language (Pamela, 2002). TOEFL has been one of the most commonly used English assessments until now. This demonstrates that the TOEFL is a reliable measure. Aside from its purpose and function as an English proficiency test, as well as its competitive existence, the TOEFL falls into the category of wellstandardized tests in general. Some who pass the TOEFL with such scores are expected to pass the regular test or be recruited. Since the 1960s, TOEFL has been touted as the most systematic test to assess non-native speakers' English proficiency skills (Sulistyo, 2009). The TOEFL test has been used in a variety of settings, not just academically (Morris \& Maxey, 2014). The TOEFL preparation program will have a positive impact on students or test takers who want to enhance their efficiency.

Joining a program to learn TOEFL in depth is known as a practice exercise for students/test takers before they take the actual test. Exposing students to the types of item formats they can experience, ensuring that they know when to guess, and assisting them in learning to distribute their time correctly are all examples of this type of planning (Mousavi et al., 2014). TOEFL is widely used to measure a person's English proficiency in an academic context. The reliability of TEOFL as a test instrument seems to have gained popularity that is difficult to compete with other similar instruments. More than that, The TOEFL's success stems from the fact that it is a highly standardized test that is used worldwide. Apart from being a measuring tool for language proficiency, in practice the TOEFL is also widely used by the wider community to register at various formal institutions, obtain scholarships, as a graduation condition, and as a condition for promotion. The practical uses of the TOEFL are very broad is a direct consequence of the great trust placed by modern institutions in this instrument.

Currently, we entered an era that encourages English to become an indispensable language in communication needs, both regionally and internationally. One measure of a person's English success can be seen from the high and the low TOEFL score. Currently, the 
English language test has been widely used for various purposes for examples undergraduate, strata- 2 and strata- 3 education, even some strata- 1 education, for scholarship requirements both at home and abroad, requirements for registering CPNS, as well as private employees, requirements for promotion, etc. There are three types of TOEFL tests: PBT (paper based test), CBT (computer based test), and IBT (Internet based test).However, in general Indonesia uses PBT in the TOEFL test. PBT has 3 skills to the TOEFL Test, there are Listening skill, Structure and Written Expression, and Reading Comprehension.

The validity of the exam is affected by how students prepare for the test of English as a foreign language (TOEFL). According to a review of the literature on the TOEFL washback effect, most studies have concentrated on classroom practices, but few have looked at students' attitudes toward TOEFL preparation and the degree to which these are influenced by their educational backgrounds. it surveyed 14 Korean language learners preparing for the TOEFL in Toronto through focus groups and formal interviews to learn about their perceptions and opinions about TOEFL preparation. As a consequence of the results, the following conclusions can be drawn: (a) Participants' learning culture appeared to influence how they prepared for the TOEFL, but their preparation is often determined by personal interests and perceptions; (b) TOEFL preparation instructions influenced how they planned for the TOEFL; (c) participants persisted in preparation practices that appeared to reduce the TOEFL's utility; and (d) participants' language education(Teachers \& Languages, 2002)

The term "New Technology" refers to language teaching communication methods in which the personal computer plays a central role (Davies \& Hewer, 2012). Apart from computers, there are other technical instruments that can be used in language learning. With one of the four language sections, each technical tool has its own set of benefits and applications (speaking, listening, reading, and writing). However, in order to use these methods effectively, the ELL student must be comfortable with computers and the internet, as well as capable of communicating with them. The information technology revolution has had a significant impact on our new lives, and technology plays an important role in the growth of today's human society. As a result, it is essential to make use of modern technical resources to assist in the challenge of English language education(Basheer Nomass, 2013). In addition to the instructor's position, technology has had a major impact on language teaching and learning. In other words, the instructor's position, combined with the role of technology, can contribute to advanced learning outcomes (Sharma, 2009).

A virtual classroom is an online learning experience that contains all course materials.(http://www.elearnportal.com/resources/getting-started/how-do-virtual-classroomswork). The virtual classroom as a framework, outside the physical boundaries of the 
conventional classroom walls, delivers the same channels for teaching and learning. Virtual classroom implementations are usually web-based via an online learning mode(Hsu et al., 1999). The Virtual Classroom is a software-based teaching and learning environment that facilitates collaborative learning among students at times and locations of their choosing through computer networks (Hiltz,1995)

Education from the virtual classroom: The reality of online teaching is a systematic resource for online learning that also serves as a regression testing resource for teachers and administrators managing the ever-changing world of online learning. Lessons from the virtual classroom: The realities of online teaching is a fantastic opportunity for organizations looking to develop high-quality online learning. The authors not only define and explain challenges, pitfalls, and concerns related to online learning, but they also provide realistic solutions focused on research-based best practices (Neuteboom, 2014). The establishment of a virtual classroom has allowed learners to use the Internet's features to create productive and constructivist learning environments (Gabriel, 2004). In this context, a modern classroom attributes have been converted with upgraded functionality into a simulated classroom. A computer classroom is learner-centered, unlike a real classroom. It offers the learners at their leisure the versatility of attendance. Instruments such as online schedules, online support manuals, books for grading online, tests and quizzes, as well as newsletters, text messaging, rooms for dialog, discussion forums and transferring files are standard features of the interactive classroom. It promotes constructive learning by creating an atmosphere with learning resources, learning content, and contextual dialogue opportunities. (Yang \& Liu,2007). A virtual classroom not only supplies the learners with course materials, but also provides them with a live, contextual and engaging atmosphere. Moreover, teachers should manage the process of teaching and learning like they would in a traditional classroom. (Yang \& Liu, 2007). However, there is no single, set way, however to incorporate a virtual classroom. There are several mechanisms that can be used by educators to introduce a simulated classroom.

In Indonesia, communication technology has advanced significantly. E-learning is an information technology program that uses the internet to connect teachers and students in the classroom (Brahimi \& Sarirete, 2015). Due to the rapid growth of Internet technology, elearning has become a more common learning method in higher education institutions.

The rise of computer-based instruments in the learning process coincided with the growth of the Internet and its applications. This is why educational institutions are increasingly relying on virtual learning environments (VLEs), which are essentially electronic learning platforms that support the conventional teaching-learning-assessment process. As a result, a 
range of applications emerged with the intention of promoting the integrated management of online learning as well as blended learning applications (Popat et al., 2007).

Based on the explanation above, research has shown that the use use of technology in education TOEFL has been shown to be an efficient learning tool for improving TOEFL score (Syakur et al., 2019). In other research, the teacher helped students to understand English and knowledge before taking the TOEFL class, according to the students every meeting should be at least 120 minutes long. Group work tasks and homework should be given by the instructor. In addition, the instructor should be on time for class (Masfufah, 2018). This study will look at how this TOEFL prep online course program helps students learn English grammar in order to improve their performance in the structure and written speech sections. Grammar is regarded as a foundational knowledge of a language that students must master before they can comprehend other language skills. Each language has its own grammar pattern. Students must have a thorough understanding of the grammar system in order to grasp language skills such as reading and listening.

The writer assumes using virtual in Test of English as Foreign Language (TOEFL) preparation by teacher, that strategy will help students to improve their TOEFL score, Is it effective for nursing students to improve TOEFL score via virtual or zoom meeting?

\section{METHOD}

A comparison of test results from the same category, the outcome is used to determine the impact of test preparation on test performance (pre-test and post-test). The mean score comparison is done using matched t-tests. The matched t-test takes the same steps as the independent samples t-test (Hatch \& Farhady, 1982). It should be noted that the findings of this study should be viewed with caution since the number of test takers is admittedly limited for making large generalizations, as (Camilli and Shepard,1994); (McNamara and Roever,1994) maintain (2006). The test takers in this sample are students who are engaged in class and participated in both the pre-test and post-test for experimental and control class.

This research was a quantitative design in virtual learning while carry out pre-test, and post-test. The students took three test. The researcher used one class to investigate whether there was an significant effective and significant improvement on the seventh year students of Institute of Health Science and Technology Muhammadiyah Palembang in TOEFL Score based on technology. The basic table of the study was explained as follows: 


\section{$\begin{array}{llll}\mathrm{E} & \mathrm{O} 1 & \mathrm{X} & \mathrm{O} 2\end{array}$}

Where: $\quad E=$ Experiment Group

$\mathrm{O} 1=$ Pre-test for Experimental Group

$\mathrm{O} 2$ = Post-test for Experimental Group

$\mathrm{X}=$ Treatment for Experimental Group

The population in this research was all of students Nursing Science Study Program Institute of Health Science and Technology of Muhammadiyah Palembang. In order to select the sample, the purposive sampling technique would be implemented, the sample of this research was the seventh semester students of Institute of Health Science and Technology Muhammadiyah Palembang. Nursing science Study program in Academic Year 2020/2021. The research took via online zoom meeting application.

The population of this research was the seventh semester students of Institute of Health Science and Technology Muhammadiyah Palembang. The totalling sample of this research was 23 students. The taking sample of this research was purposive sampling technique.

The data collection of this research was carry out online through Zoom meeting, the data of collection in this research was the test score TOEFL pre-test and post-test. The instrument of this research taken by test TOEFL (Philips, 2004)

In analyzing the data, this research designs in e-learning while still carrying out pretest, and post-test. It was three TOEFL score results in pre-test and post-test would had the same or different treatment. The hypothesis was based on pre-test and post-test differences in the impact of treatment on TOEFL ratings. The data were analyzed by the use of a dependent t-Test. The t-Test was used to compare the results of between pre-test and post-test score.

\section{FINDINGS \& DISCUSSION}

The findings cover: (1) the results of the total Pre-test and Post-test TOEFL score; (2) the statistical analysis results. The following is a recapitulation of the TOEFL score for preand post-tests. The test was adopted from Longman Introductory Course for The TOEFL test.

Table 2. The Results of the Total TOEFL score

\begin{tabular}{ccc}
\hline St & PRE TEST & POST TEST \\
\hline 1 & 483 & 576 \\
2 & 463 & 480 \\
3 & 470 & 493 \\
4 & 517 & 526
\end{tabular}




\begin{tabular}{ccc}
5 & 507 & 500 \\
6 & 430 & 420 \\
7 & 240 & 610 \\
8 & 320 & 406 \\
9 & 456 & 456 \\
10 & 250 & 596 \\
11 & 263 & 420 \\
12 & 346 & 383 \\
13 & 500 & 556 \\
14 & 306 & 513 \\
\hline
\end{tabular}

The statistical analysis results

The following is the statistical analysis of the test results. SPSS 22 was used to get the results. Table 3. Paired Sample t-Test Results

Paired Samples Correlations

\begin{tabular}{lcccc}
\hline & N & Correlation & Sig. \\
\hline Pair 1 & pre-test \& post-test & 15 & .063 & .824 \\
\hline
\end{tabular}

Paired Samples Test

\begin{tabular}{|c|c|c|c|c|c|c|c|c|c|}
\hline & & \multicolumn{5}{|c|}{ Paired Differences } & \multirow[b]{4}{*}{$\mathbf{t}$} & \multirow[b]{4}{*}{ df } & \multirow[b]{3}{*}{$\begin{array}{l}\text { Sig. } \\
(2-\end{array}$} \\
\hline & & \multirow[b]{3}{*}{ Mean } & \multirow{3}{*}{$\begin{array}{c}\text { Std. } \\
\text { Deviation }\end{array}$} & \multicolumn{3}{|c|}{ 95\% Confidence } & & & \\
\hline & & & & \multirow{2}{*}{$\begin{array}{l}\text { Std. Error } \\
\text { Mean }\end{array}$} & \multicolumn{2}{|c|}{$\begin{array}{c}\text { Interval of the } \\
\text { Difference }\end{array}$} & & & \\
\hline & & & & & Lower & Upper & & & tailed) \\
\hline Pair & pre- & -96.93333 & 122.37849 & 31.59799 & -164.70428 & -29.16238 & -3.068 & 14 & .008 \\
\hline 1 & test - & & & & & & & & \\
\hline & post- & & & & & & & & \\
\hline & test & & & & & & & & \\
\hline
\end{tabular}

The paired sample t-Test showed that the Sig value. (2-tailed) was $0.008<0.05$. Because Sig. (2-tailed) of 0.008 was smaller than 0.05 , it could be concluded that there was a significant effect using virtual classroom in TOEFL preparation.

The writer would like to discuss the results in this section. The aim of the discussion was to explain how virtual classroom helped students increase their TOEFL scores and the advantages of virtual classroom for teachers and students in the learning process.

The success of the virtual Classroom in raising students' TOEFP readiness scores can be seen in the results of the pretest. Listening comprehension, structure and written expression, 
and reading comprehension were assessed in the pretest, with listening comprehension (50 question items - 35 minutes), structure and written expression (40 question items - 25 minutes), and reading comprehension (50 question items - 50 minutes) being the three skills tested. In other test formats, these sections will be different. There were some changes in students' post-test scores after treatment.

One-group experiment design, with pre-posttest design, is used to perceive the effectiveness of the course. To verify the hypotheses, The paired sample t-test and independent sample t-test results were both 0.008 , which was less than 0.05 . It means that there was significant effective using virtual classroom in TOEFL preparation for students Nursing Science Study Program Institute of Health Science and Technology of Muhammadiyah Palembang.

Students become more motivated and gain a better knowledge of the learning materials when they participate in online group discussions (Haverback, 2009), It means that if the online learning environment can make students feel more at ease and confident in their study, the information will be easier to comprehend and they will be more driven to learn. Weekly assignments linked to TOEFL, including as listening, structure and written expression, and reading comprehension, are given to students in this online course. The first six months' worth of exercises focus on structure and textual language. At the outset of the learning process, this online course program aims to teach structure and written expression. It is considered that pupils have a thorough comprehension of the structure as the fundamental level of a language before moving on to the next session The exercises are delivered on a weekly basis. Its goal is to familiarize students with TOEFL questions, particularly in the structure and written expression sections. This practice in this online course is intended to help students prepare for the TOEFL test. Students who join in this program are expected to achieve higher grades and complete the scholarship's requirements(Sudrajat \& Astuti, 2018).

The TOEFL online education program might help you prepare for the test. In order to improve their score in the structure and written expression portion, students must learn English grammar. Grammar is regarded as a foundational knowledge of a language that students must master before they can comprehend other language skills. Each language has its own grammar pattern. Students must have a thorough comprehension of the grammar structure in order to acquire language abilities such as reading, writing, speaking, and listening. This is why the founder of the preparation test program started with the most fundamental topics, such as structure and written expression. The TOEFL preparation program may have a positive impact on students or test takers who want to improve their score. 


\section{CONCLUSION}

Based on the data analysis, the researcher draws some conclusion as follows: Referring to the research questions, there are significantly improve using virtual classroom in TOEFL preparation.

Based on the above conclusion, the writer offers the following suggestions to teachers, future researchers, and anyone who reads this research: (1) For Education, utilizing online Classroom in the teaching - learning activities is one of the most effective learning techniques for teaching English or other classes because it can improve academic interest in learning; (2)For Students, utilizing online Classroom can improve students interest in learning and student activity because students are more interested to learn in this age of technology;(3) For English lecturers, online Classroom is one tool that can be considered in TOEFL preparation to help students improve their score; (4) For school high school students, it is expected to be more interested in learning if online Classroom is implemented, so it is recommended that high school students maintain approaches or learning strategies in class.

\section{REFERENCES}

Basheer Nomass, B. (2013). The Impact of Using Technology in Teaching English as a Second Language. English Language and Literature Studies, 3(1), 111-116. https://doi.org/10.5539/ells.v3n1p111.

Brahimi, T., \& Sarirete, A. (2015). Learning outside the classroom through MOOCs. Computers in Human Behavior. https://doi.org/10.1016/j.chb.2015.03.013.

Camilli, G., \& Shepard, L. A. (1994). Methods for identifying biased test items. California: Sage.

Davies, G., \& Hewer, S. (2012). Introduction to new technologies and how they can contribute to language learning and teaching. Module 1.1 in Davies G. (ed.), Information and Communications Technology for Language Teachers (ICT4LT), Slough, Thames Valley University [Online]. Retrieved fromhttp://www.ict4lt.org/en/en_mod1-1.htm.

ETS. (2009). "Test and Score Data Summary for TOEFL Internet-Based and Paper- Based Tests JANUARY." (December).

Gabriel, M. (2004). Learning together: Exploring group interactions online. Journal of DistanceEducation, 19(1), 54-72. http://www.jofde.ca/index.php/jde/article/view/105/90.

Hatch, E., \& Farhady, H. (1982). Research design and statistics for applied linguistics. Rowley, 
Mass: Newbury House.

Haverback, H. R. (2009). Uncharted territory in a reading education classroom. Reading Today. Facebook.

HD. (2004). Brown. Language Assessment: Principle and Clasroom Practices. New York: Pearson Education, 2004.

Hiltz, S.R. (1995). Teaching in a Virtual Classroom. International Journal of Educational Telecommunications, 1(2), 185-198. Charlottesville, VA: Association for the Advancement of Computing in Education (AACE). Retrieved March 24, 2021 from https://www.learntechlib.org/primary/p/15158/.

Hsu, S., Marques, O., Khalid Hamza, M. \& Alhalabi, B. (1999). How to design a virtualclassroom: 10 easy steps to follow. T.H.E. Journal, 27(2), 96-109. http://www.eric.ed.gov/ERICWebPortal/contentdelivery/servlet/ERICServlet?accno=ED 437027.

Isaac, W, and W Justin. (2009). "Relationship Between TOEFL Score and Academic Success for International Engineering Students.” Journal of Engineering Education 98(4): 389.

Kabilan, M. K., Ahmad, N., \& Abidin, M. J. Z. (2010). Facebook: An online environment for learning of English in institutions of higher education? The Internet and Higher Education, 13(4), 179- 187.

Kurasi, Syamsuriana. (2012). "The Correlation Between The Students' Attitude and English Proficiency of the Second Year Students of SMK Negeri 1 Enrekang." UIN Alauddin Makassar.

Masfufah, S. (2018). Indonesian College Students' Perceptions Of TOEFL Preparation C. Journal of English Education, Literature, and Culture, 3(1), 66-77. http://lppmunissula.com/jurnal.unissula.ac.id/index.php/edulite/article/view/2166/1846.

McNamara, T., \& Roever, C. (2006). Validity and the social dimension of language testing. Language Learning, 56(2), 9-42.

Morris, M., \& Maxey, S. (2014). The importance of english language competency in the academic success of international accounting students. Journal of Education for Business, 89(4), 178- 185. https://doi.org/10.1080/08832323.2013.819315.

Mousavi, S. A., Arizavi, S., \& Namdari, N. (2014). The effect of test preparation on the test performance the case of the IELTS and TOEFL iBT reading tests. International Journal 
of English and Education, 3(2), 10-22.

Munadia. (2016). An Analysis of EFL Studnts' Difficulty in the TOEFL Structure and Written Expression Section (Issue September).

Neuteboom, R. K. (2014). Book Review: Lessons from the Virtual Classroom: The Realities of Online Teaching. Journal of Teaching and Learning with Technology, 10(June), 105106. https://doi.org/10.14434/jotlt.v3n1.4279.

Nimasari, E. P., Mufanti, R., \& Gestanti, R. A. (2019). SEKOLAH TOEFL as a platform to integrate technology and online learning resources in ELT. Asian EFL Journal, 23(3), 90104.

Pamela J. Sharpe.(2002) How to Prepare for the TOEFL Test. Jakarta: Bina Rupa Aksara.

Phillips, D. (2004). Longman Introductory Course for the TOEFL Test: The Paper Test.

Rezkiani. (2019). The Difficulties Faced by The EFL Students in The TOEFL Test ( A Case Study At English and Literature Department ).

Sharma, P. (2009). Controversies in using technology in language teaching. Retrieved from http://www.teachingenglish.org.uk/articles/controversies-using-technology-languageteaching.

Sudrajat, W. N. A., \& Astuti, E. R. (2018). Students' Perceptions of the Use of TOEFL Preparation Online Course on the Test Performance: The Case of TOEFL Structure and $\begin{array}{llll}\text { Written } & \text { Expression } & \text { Test. }\end{array}$ https://doi.org/10.21512/humaniora.v9i3.4807.

Sulistyo, G. H. (2009). Toefl in a Brief Historical Overview From Pbt To Ibt. Bahasa Dan Seni, $2,116-127$.

Syakur, A., Junining, E., \& Sabat, Y. (2019). Application of E - Learning as a Method in Educational Model to Increase The TOEFL Score in Higher Education. 3(November), 111-116.

Teachers, K., \& Languages, O. (2002). Korea TESOL. 5(1).

Papageorgiou S, Cho Y.(2014) An investigation of the use of TOEFL® JuniorTM Standard scores for ESL placement decisions in secondary education. Language Testing. 31(2):223239. doi:10.1177/0265532213499750.

Popat, K, MacLean, H, Heppell, S. (2007). Virtually There: Learning Platforms YHGfL/Cleveratom ISBN 987-0-9556006-0-9.

Wulandari, N. (2016). Barriers Of Teaching TOEFL In Indonesia.Lantip : Jurnal Ilmu Sosial Dan Ekonomi Universitas Respati Yogyakarta, 6(1), 1-12. http://lantip.respati.ac.id/index.php/LANTIP/article/view/12.

Yang, Z. \& Liu, Q. (2007). Research and development of Web-based virtual online 
http://dx.doi.org/10.1016/j.compedu.2004.12.007. 